\title{
МОРФОЛОГІЧНА ХАРАКТЕРИСТИКА СТРУКТУРНИХ КОМПОНЕНТІВ ХРЯЩОВОГО ПОКРИТТЯ КОЛІННОГО СУГЛОБА НА УЛЬТРАСТРУКТУРНОМУ РІВНI В НОРМI
}

\author{
Войценко К. І., Пальтов Є. В., Кривко Ю. Я. \\ Львівський національний медичний університет імені Данила Галищького, кафедра нормальной \\ анатомії, м. Львів, Україна
}

DOI: https://doi.org/ 10.31435/rsglobal_ws/31012019/6298

\begin{tabular}{|c|c|}
\hline ARTICLE INFO & ABSTRACT \\
\hline Received: 21 November 2018 & $\begin{array}{l}\text { The work, presented below, aimed at studying the peculiarities of structural } \\
\text { organization of the articular cartilage coating of the knee joint in the norm. }\end{array}$ \\
\hline Published: 31 January 2019 & The objective was achieved by microscopic visualization of cellular \\
\hline KEYWORDS & we applied generally accepted, conventional methods. \\
\hline $\begin{array}{l}\text { articular cartilage, } \\
\text { ultrastructure, } \\
\text { rat, } \\
\text { norm. }\end{array}$ & $\begin{array}{l}\text { The results of the study will allow to form an ultrastructural base that can be } \\
\text { further used for a comparative study of the structural components of the } \\
\text { articular cartilage in norm as opposed to morphological changes of some } \\
\text { elements in different stages of acute, subchronic and chronic experimental } \\
\text { opioid exposure. }\end{array}$ \\
\hline
\end{tabular}

Citation: Войценко К. І., Пальтов С. В., Кривко Ю. Я. (2019) Morfolohichna Kharakterystyka Strukturnykh Komponentiv Khriashchovoho Pokryttia Kolinnoho Suhloba na Ultrastrukturnomu Rivni v Normi. World Science. 1(41), Vol.2, doi: 10.31435/rsglobal_ws/31012019/6298

Copyright: (C) 2019 Войценко К. І., Пальтов С. В., Кривко Ю. Я. This is an open-access article distributed under the terms of the Creative Commons Attribution License (CC BY). The use, distribution or reproduction in other forums is permitted, provided the original author(s) or licensor are credited and that the original publication in this journal is cited, in accordance with accepted academic practice. No use, distribution or reproduction is permitted which does not comply with these terms.

Результати статі відповідають плану наукових досліджень Львівського національного медичного університету імені Данила Галицького і є частиною науково - дослідної теми кафедри нормальної анатомії «Структурна організація, ангіоархітектоніки та антропометричні особливості органів у внутрішньо та позаутробному періодах розвитку, за умов екзо - та ендопатогених факторів» (номер держреєстрації 0115U000041) впродовж 2015 - 2019 pp.

Вступ. Своєчасність і актуальність даного дослідження визначається широким використанням в експериментальних дослідженнях лабораторних тварин зокрема щурів $[1,2], 3$ метою моделювання експериментальних патологічних станів [3, 4]. 3 метою адекватного вивчення патологічних змін в певних органах тварини на різних етапах перебігу експериментального патологічного процесу необхідно володіти фундаментальними знаннями норми як на макро-, мікро- та ультраструктурному рівнях [5-7].

Вищезазначене окреслело мету нашої роботи, що полягала у вивченні особливостей структурної організації елементів хрящового покриття колінного суглоба на ультраструктурному рівні в нормі.

Матеріали та методи дослідження. Матеріалом дослідження слугували статево зрілі, безпородні щури-самці в кількості 15-ти тварин, масою 80 г, віком 4,5 місяців. Усі тварини знаходились в умовах віварію і робота, що стосувалася питань утримання, догляду, маркування та всі інші маніпуляції проводилися із дотриманням положень “Європейської конвенції про захист хребетних тварин, які використовуються для експериментальних та інших наукових цілей” [Стразбург, 1985], “Загальних етичних принципів експериментів на тваринах”, 
ухвалених Першим Національним конгресом 3 біоєтики [Київ, 2001]. Комісією 3 біоєтики Львівського національного медичного університету імені Данила Галицького встановлено, що проведені наукові дослідження відповідають етичним вимогам згідно наказу МОЗ України № 231 від 01. 11. 2000 року ( протокол № 10 від 26.12. 2011 року).

Перед проведенням забору біопсійного матеріалу тварину присипляли дибутиловим ефіром. Як матеріал для ультраструктурного дослідження використали хрящі дистального епіфізу стегнової та проксимального епіфізу великогомілкової кісток колінного суглоба щурів. Ультраструктурні препарати готували за загальноприйнятою методикою [8 - 10].

Результати дослідження. В результаті ультраструктурного дослідження пошарової організації клітинного складу хрящового покриття колінного суглоба інтактної групи щурів нами було отримано наступні результати. Структурна організація епіфізарного хряща колінного суглоба інтактних тварин встановили збережену архітектоніку хрящової тканини. Зовнішня поверхня безклітинної пластинки гладка, вкрита тонким електроннощільним шаром, без пошкоджень. У безклітинній пластинці розташовується значна кількість мікрофібрил колагенових волокон, що впорядковані паралельно до суглобової поверхні. Поодинокі хондроцити поверхневої зони видовженої форми, вузькі. Ядро хондроцитів поверхневої зони об'ємне, овальне, містить незначну кількість гетерохроматину у вигляді темної смужки по периферії ядра. Центральна частина ядра заповнена переважно еухроматином, 3 дрібними включеннями гетерохроматину. Поверхня хондроцитів нерівна, на ній візуалізуються короткі цитоплазматичні відростки. Об'єм цитоплазми хондроцитів поверхневої зони незначний. У ній зосереджується значна кількість цистерн гладкої ендоплазматичної сітки, поодинокі мітохондрії, короткі профілі гранулярної ендоплазматичної сітки, рибосоми, а також дрібні електроннощільні включення. Поблизу ядра проглядається комплекс Гольджі, з поодинокими секреторними міхурцями. Фібрили колагенових волокон матриксу поверхневої зони тонкі, матрикс однорідний, його волокнисті компоненти чітко впорядковані. Хондроцити перехідної зони округлої форми розташовуються в лакунах ізогенними парами як це показано на рис. 1.

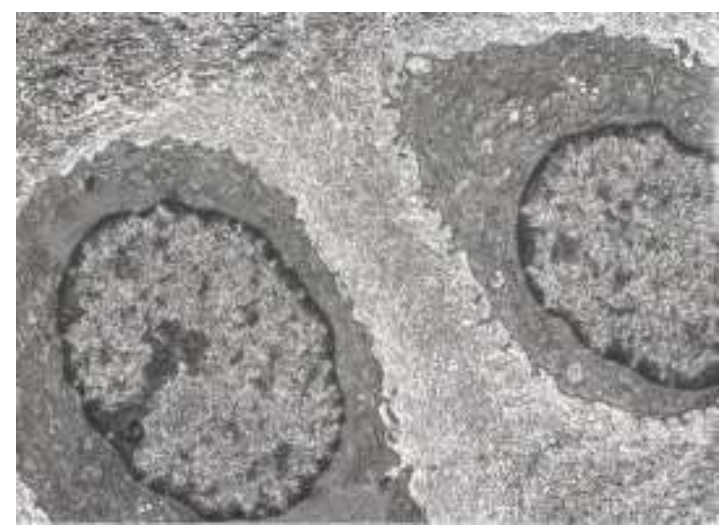

Рис. 1. Ультраструктура хондроцитів перехідної зони хрящового покриття колінного суглоба щура в нормі. Зб. х 6000.

На поверхні хондроцитів цієї зони чітко візуалізуються мікроворсинки та вирости як це видно рис. 2. Ядро заповнене переважно еухроматином, 3 незначними включеннями гетерохроматину, що розташований переважно в периферичних ділянках поблизу каріолеми. Профілі гранулярної ендоплазматичної сітки містять білковий вміст, на ії мембранах візуалізуються рибосоми. Комплекс Гольджі добре виражений, у його цистернах розташовуються везикули. У цитоплазмі також містяться секреторні міхурці, поодинокі мітохондрії, вільні рибосоми та поодинокі зерна глікогену. У хондроцитах перехідної зони 3 добре вираженою гранулярною ендоплазматичною сіткою, що містить значну кількість рибосом цитоплазма переважно помірної електронної щільності, що свідчить про високу активність синтезу білків, зокрема колагену. 


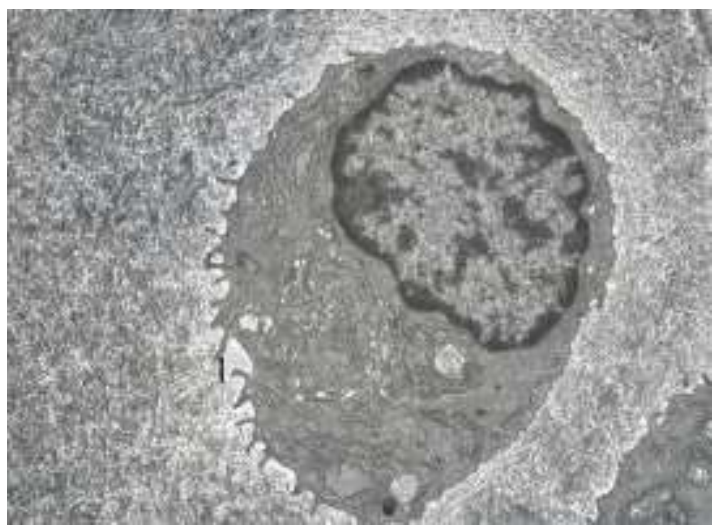

Рис. 2. Ультраструктура хондроцитів перехідної зони хрящзового покриття колінного суглоба иурра в нормі. 3б. х 6000.

1 -мікроворсинки хондроцчита.

Поруч також візуалізуються хондроцити 3 добре розвиненою гладкою ендоплазматичною сіткою, цитоплазма яких темна, електроннощільна як це показано рис. 3, також містить складно організований комплекс Гольджі, із значною кількістю секретероних міхурців 3 гранулами. У таких хондроцитах відбувається інтенсивний синтез глікозаміногліканів. Територіальний матрикс перехідної зони, що оточує хондроцити збережений, містить колагенові фібрили та протеоглікани. Фібрили колагенових волокон між територіального матриксу мають різну орієнтацію, проникають в перилакунарні ділянки, формують сітку.

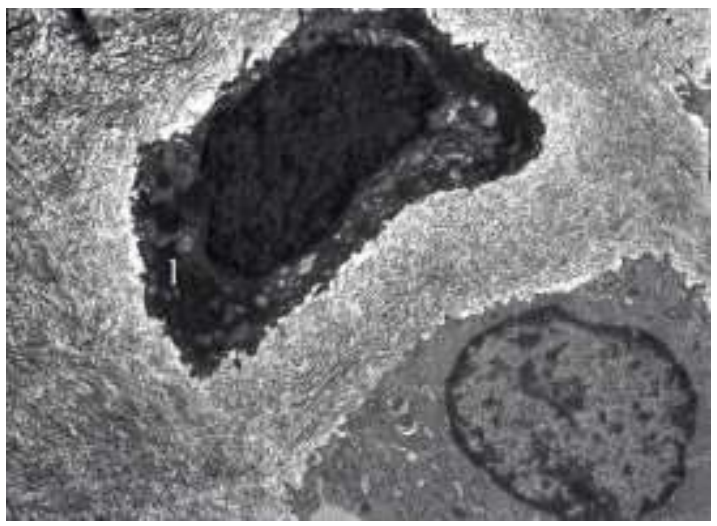

Рис. 3. Ультраструктура хондроцитів перехідної зони хрящуового покриття колінного суглоба иура в нормі. 3б. х 6000

1 - темна циитоплазма гладкої ендоплазматичної сітки.

У зоні проліферуючого хряща хондроцити еліпсоїдної форми, розташовуються у складі радіальних колонок. Ї̈х краї нерівні, формують неоднорідні відростки. Ядро об'ємне, ендоплазматичний ретикулум виражений слабо. Часто виявляють фігури мітозів хондроцитів зони проліферуючого хряща. Фібрили колагенових волокон між територіального матриксу товстіші, у порівнянні з колагеновими волокнами поверхневої та перехідної зон.

У зоні гіпертрофії локалізуються в основному об'ємні зрілі хондроцити із електронносвітлою цитоплазмою, що містить чисельні вакуолі, ліпідні включення та чисельні зерна глікогену, нагромадження яких $є$ сигналом для оссифікації. Подекуди трапляються поодинокі хондроцити, об’єм цитоплазми яких збільшується унаслідок гіперплазії гранулярної ендоплазматичної сітки, комплекса Гольджі та мітохондрій. Зустрічаються хондроцити у стані дегенерації, некрозу, апоптозу та дезінтеграції. За розвитку альтеративних змін відзначається редукція органел, збільшення кількості зерен глікогену, ліпідних включень та цитоплазматичних волоконець. Ядро дегенеруючих хондроцитів поліморфне, зморщене, 3 ущільненою інтенсивноосміофільною однорідною нуклеоплазмою, органели зазнають редукції, подекуди зустрічаються вакуолізовані мітохондрії, поодинокі цистерни гранулярної 
ендоплазматичної сітки. Міжтериторіальний матрикс перехідної зони об’ємний, однорідний, помірної електронної щільності, дрібнозернистий, містить товстіші ніж у поверхневій зоні фібрили колагену, а також нитки протеогліканів різної товщини. Колагенові волокна мають різнонаправлену орієнтацію, пронизують міжтериторіальний маткрикс, а також проникають у перилакунарні ділянки.

У ділянці кальцифікованого хряща локалізуються переважно як гіпертрофовані хондроцити, що розташовуються на значній віддалі одні від одних, а також хондроцити в стані дегенерації. Лакуни широкі, зустрічаються лакуни без хондроцитів. Ядра хондроцитів зменшені в об'ємі, щільні, цитоплазматичні структури організовані слабо, із значною кількістю гранул глікогену, ліпідними включеннями.

Висновки:

1. Зовнішня поверхня безклітинної пластинки гладка, вкрита тонким електроннощільним шаром. У цій зоні безклітинної пластинки розташовується значна кількість мікрофібрил колагенових волокон, що впорядковані паралельно до суглобової поверхні. Поодинокі хондроцити поверхневої зони видовженої форми та вузькі.

2. Хондроцити перехідної зони округлої форми розташовуються в лакунах ізогенними парами. На поверхні хондроцитів цієї зони чітко візуалізуються мікроворсинки та вирости.

3. Структурна організація хондроцитів перехідної зони свідчить про високу активність синтезу білків, зокрема колагену.

4. У зоні гіпертрофії локалізуються в основному об'ємні зрілі хондроцити із електронносвітлою цитоплазмою, що містить чисельні вакуолі, ліпідні включення та чисельні зерна глікогену, нагромадження яких є сигналом для оссифікації.

\section{ЛIТЕРАТУРА}

1. Paltov YeV. Morphological features of the anatomy of the arterial bed of the neck and maxillofacial area of the rat are normal. Scientific herald of the Lviv National Academy of Veterinary Medicine. SZ Gzhytsky. 2004;6-1(1):113-119. [Published in Ukrainian]

2. Paltov YeV. Roengenoanatomy of the arteries of the rat head and neck. Clinical anatomy and operative surgery. 2004;3(2):26-29. [Published in Ukrainian]

3. Paltov YeV, Kryvko YuYa, Tomashova SA, Vil'hova IV, Matkivskyi RM. The state of microstructural organization of soft tissues of periodontal disease in white rats in norm and their change at different stages of the course of experimental streptozotocin diabetes mellitus. Bulletin of the Sumy State University. 2006;2(86):36-43. [Published in Ukrainian]

4. Paltov YeV, Kryvko YuYa. The ultrastructural organization of soft tissues of periodontal disease in white rats is normal and the dynamics of their changes during the course of streptotsotocin-induced experimental diabetes mellitus. World of Medicine and Biology. 2006;3:35-44. [Published in Ukrainian]

5. Paltov YeV, Chelpanova IV, Fik VB, Vil'hova IV, Kyryk KhA, Kryvko YuYa. Pathomorphological changes in layers of retina for six weeks of opioid exposure experiment. World of Medicine and Biology. 2017;2(60):146-150. [Published in Ukrainian]

6. Paltov YeV, Kryvko YuYa. Pathological changes in the layers of the retina after eight weeks of opioid influence at the experiment. Bulletin of problems biology and medicine. 2017;4.2(140):118-122. [Published in Ukrainian]

7. Paltov YeV, Fik VB, Kryvko YuYa. Pathomorphological changes in the retina layer at the end of the fourth week of opioid effect. Natural Science Readings abstracts booc; 2018 May 18; Sosnowiec-Bratislava; 2018. p. 30-32.

8. Glauert AM. Fixatson, dehydration and embedding of biologicalspecimens. In: Practical methods in electron microscpi. North-Hollond: American Elsevier; 1975. 207 p.

9. Stempak JG, Ward RT. An improved staining method for electron microscopy. J Cell Biol. 1964;22(3):697-701.

10. Reynolds ES. The use of lead citrate at high $\mathrm{pH}$ as an electronopague stain in tlectron microscopy. J Cell Biol. 1963;17:208-212. 